Portland State University

PDXScholar

6-16-2021

\title{
Migrant Success: Sanctuary Law and Resources for Migrants in Portland, Oregon
}

Jessica Risney

Portland State University

Follow this and additional works at: https://pdxscholar.library.pdx.edu/honorstheses

Part of the International and Area Studies Commons, and the Public Policy Commons Let us know how access to this document benefits you.

\section{Recommended Citation}

Risney, Jessica, "Migrant Success: Sanctuary Law and Resources for Migrants in Portland, Oregon" (2021). University Honors Theses. Paper 1064.

https://doi.org/10.15760/honors.1090

This Thesis is brought to you for free and open access. It has been accepted for inclusion in University Honors Theses by an authorized administrator of PDXScholar. Please contact us if we can make this document more accessible: pdxscholar@pdx.edu. 
Migrant Success: Sanctuary Law and Resources for Migrants in Portland, Oregon

\author{
by \\ Jessica Risney
}

An undergraduate honors thesis submitted in partial fulfillment of the requirements for the degree of

Bachelor of Arts

in

University Honors

and

International Studies: Global Studies

Thesis Adviser

Rebecca Summer

Portland State University 


\section{Introduction}

The word "sanctuary" has been broadly defined by a number of scholars within the field of migration, and for the purpose of clarity in this thesis I offer the definition of authors Villazor and Gulasekaram: "a range of policies and programs adopted by public and private entities or organizations that decline or limit voluntary participation in federal immigration enforcement practices or seek to shield noncitizens from federal enforcement efforts" (2019). This means that local authority figures within designated sanctuary cities or states in the United States are not necessarily obligated to cooperate with federal immigration authorities; "they are simply declining to use local resources to enforce federal laws, because that is the responsibility of the federal government," (Point: Sanctuary Cities Protect Local Economies and Communities, 2019). This principal policy allows undocumented citizens to worry less about deportation as a daily fear in order to live and work as part of a community.

Anti-immigrant groups have unfortunately caused the word "sanctuary" to be "generally associated with the unlawful facilitation of the continued presence of unauthorized immigrants and their families in this country" (Colbern et al., 2019). However, other authors argue that sanctuary cities "[foster] a stable community in which crime is addressed more efficiently and otherwise law-abiding, tax-paying residents continue to contribute to society" (Point: Sanctuary Cities Protect Local Economies and Communities, 2019). Those who implement sanctuary policies in cities often consider the benefits of migrants participating to a greater degree in the economy and providing more labor instead of worrying about the legal status of the people working and contributing to the city in their daily lives. Economically, cities benefit migrants by providing jobs and migrants benefit cities by settling, taking jobs, and then paying taxes. 
The state of Oregon implemented a sanctuary law in 1987 to protect the growing numbers of unauthorized migrant communities settling in the state. This law says that state and local authorities are not allowed to use federal money or reinforcement to apprehend migrants with foreign citizenship whose only crime is being in the country illegally (Sanctuary Policies, 2019). The City of Portland also issued Resolution No. 37277 in 2017 to "declare the City of Portland a Welcoming City, a Sanctuary City, and an Inclusive City for all” (Valderrama, 2017). There are a number of different migrant community groups living in the greater Portland area, and all of them require different levels of assistance in order to succeed. In recognition of this, there are many nonprofit organizations in the area that work for the benefit of those migrant communities in order to help migrants make a smooth transition into life in the United States, and ensure continued success.

In this thesis I ask how Oregon's 1987 sanctuary policy impacts the migrant communities in Portland with a specific focus on undocumented migrants. I examine the impacts of Oregon's sanctuary law on the migrant communities within the Portland area, as well as the resources and opportunities offered to help those communities thrive. I also look at some of the historical and more recent efforts to repeal Oregon's sanctuary law and the Trump-era federal efforts to work around this state law. I argue that the sanctuary policy in Oregon law positively impacts the lives of migrants to Portland in two ways: by laying the foundation for an increase in community safety, and by expanding the capacity of immigrant and refugee-focused institutions. These positive impacts are important to recognize in order to reinforce the necessity of sanctuary policies, especially in comparison to the federal immigration policies of the Trump administration that sought to harm and displace migrants. 


\section{Literature Review}

There are a number of scholars who study different aspects of sanctuary cities and policies. Some assess the meaning of sanctuary itself (Paik, 2017; O’Brien et al., 2019; Colbern et al., 2019), the types of institutions that can and do adopt sanctuary policies for migrants (Villazor \& Gulasekaram, 2019), and the social networks among both documented and undocumented migrants with similar backgrounds, including country of origin, religious affiliation, language and dialect, and government-supported resettlement networks (Hardwick \& Meacham, 2005; Hume \& Hardwick, 2005). Among this group of scholars that study sanctuary cities and policies, it is important to note that their writing often contains elements of each of these subsections. For example, the articles by Hardwick \& Meacham (2005) and Hume \& Hardwick (2005) are about specific migrant populations from Russia, Ukraine, and Vietnam moving to the Pacific Northwest, but they also provide an in depth look at the institutions that are set up to help those migrants. These authors' ideas are useful for anyone studying the idea of sanctuary and how it is best implemented, and their work provides a background for further individual study of sanctuary places.

There is a second group of authors within this community who compile information about specific institutions (Tebben, 2017), cities (Morrison \& Swanson, 2019; Houston, 2019), groups of migrants (Hardwick, 2006; Lotspeich, 2003), and sanctuary policies (Colbern, 2019; O’Brien et al., 2019). Nonprofit organizations and government agencies whose main purpose is to help refugee and migrant communities often assess community needs and put out reports to promote equity and inclusion through resource availability for both authorized and unauthorized migrant communities (IRCO 2019 Impact Report, 2019; Tebben, 2017). Larger institutions like 
these and the authors that write directly about migrant communities are highly influential in the policy process, because they can act as the unified voice of these migrant groups.

Despite knowledge about different aspects of sanctuary laws and the institutions and policies designed to support migrants, there is not much information about the direct impacts of sanctuary policies in local and state governments around the United States. There is limited information available about the direct impacts of Oregon's sanctuary law and the communities it fosters in the Portland metropolitan area, and this thesis adds specificity to the existing literature by focusing expressly on undocumented migrants in Portland.

\section{Background on Portland's Migrant Communities}

\section{Portland's Migrant Communities}

According to the US Census Bureau's 2019 American Community Survey estimate, there are approximately 87,000 foreign-born people living in the city of Portland (2019). Of these, about 18,000 people are undocumented immigrants, and about 14,000 are likely refugees (New American Economy, 2020). Many migrants to Portland and the Pacific Northwest come for the communities that have already been established in the area, including ethnic and religious communities. One example of this is migrants of Slavic descent, who began to come to the region on a basis of religious persecution and have continued to do so since the late 1980s and early 1990s (Hardwick \& Meacham, 2005). Slavic migrants are one example of a group that entered the United States with refugee status and many decided to settle here permanently, "facilitated by a network of social service organizations and refugee assistance groups with capacities to work with the Slavic community" (Curry-Stevens \& Coalition of Communities of Color, 2014). An example of a specific, often unauthorized migrant group that benefits from 
Oregon's sanctuary law directly is South and Central American migrants who cross the border illegally and settle in the Portland area. These migrants, according to the 2000 census, are often migrants with little to no proficiency in English, who struggle with access to public services and end up in poverty (Lotspeich et al., 2003). As of the American Community Survey in 2019, it is estimated that over 50 percent of foreign-born residents speak English less than "very well," and about 4,000 households sat below the poverty line (2019).

Different refugee groups often have much different experiences entering the United States than undocumented migrants, in part because a large number of them are permitted entry. In 1980, the Refugee Act "created The Federal Refugee Resettlement Program to provide for the effective resettlement of refugees and to assist them to achieve economic self-sufficiency" (The Refugee Act, 2012). Although refugees have a legal basis to be in the United States, they are often still vulnerable to a precarious legal status. Since 1980, there has been an annual "ceiling" for the number of refugees admitted into the country. The years 2017-2020 had the lowest resettlement ceilings since the Refugee Act was enacted (U.S. Annual Refugee Resettlement Ceilings and Number of Refugees Admitted, 1980-Present, 2020). Refugees like those in the Temporary Protected Status (TPS) program from Somalia, South Sudan, Syria, and Yemen were told in November 2019 that their protected status would be extended until early January 2021, and then refugees and unauthorized migrants from countries with protected refugee status would be forced to return to their home countries (Cohn et al., 2019). Programs like TPS create a grey zone between authorized and unauthorized migration, as a number of people might come into the country with a temporary visa, and overstay the bounds of their legal status. The opposite is also true, that someone from an eligible country can apply for TPS after entering the United States without authorization or after letting a temporary visa run out (Cohn et al., 2019). 
Undocumented migrants mostly do not have access to the same protections as refugees. There are three ways that the federal government regards unlawfully present noncitizens in terms of receiving benefits. The federal power to treat citizens and noncitizens differently was affirmed through case precedent in 1976, but states and localities have a constitutional obligation to treat citizens and noncitizens equally under the Equal Protection Clause. In addition, Congress has issued statute 8 U.S.C. $\S 1621$, "restricting state and local rights to offer benefits and services to noncitizens" unless their immigration status is specifically listed within the statute (Ayers, 2018). For those noncitizen statuses listed within $\S 1621$ as eligible for state and local benefits, Congress allows states to choose whether or not to offer those benefits through 8 U.S.C. $\S 1622$. Finally, Congress requires states and localities through $\S 1622(\mathrm{~b})$ to offer benefits to permanent residents, refugees, and asylees after a certain period of time (Ayers, 2018).

\section{Organizations Working on Behalf of Migrant Communities}

Portland has a number of organizations that work for the benefit of migrant groups within the region. These generally fall into two categories; the first are those that provide direct services to migrants, regardless of documentation status. One important organization in this category is

the Immigrant \& Refugee Community Organization (IRCO), which works to enhance the lives of multiple immigrant groups, help them address their needs, and break down barriers to integration in the community. IRCO itself receives support and funding from dozens of public and private organizations, which allows them to financially support migrant programs and builds a connection with other organizations in order to direct migrants elsewhere for specialty expertise (IRCO 2019 Impact Report, 2019). IRCO publishes regular community needs assessments, and works closely with migrant communities in a way to support their needs as quickly and 
efficiently as possible. Another organization in this first category is Causa, which "works to improve the lives of Latino immigrants and their families in Oregon through advocacy, coalition building, leadership development, and civic engagement" (Causa, 2020). Causa runs programs for leadership development and community organizing that fight for social justice, advocates for immigration reform, and promotes and actively increases civic engagement.

The second category is the organizations that provide legal services to migrants. Metropolitan Public Defense (MPD) is a nonprofit law firm that provides quality public defense and legal representation to low-income and below poverty level people. Since a number of undocumented migrants fall into this category, MPD is occasionally responsible for representing them, always with the purpose of improving outcomes, like long term stability (Metropolitan Public Defender, 2021). Similarly, the American Civil Liberties Union (ACLU) "has been one of the nation's leading advocates for the rights of immigrants, refugees and non-citizens, challenging unconstitutional laws and practices” (Immigrants’ Rights, 2019). Where MPD focuses on legal representation for people, the ACLU focuses on the fight for civil liberties and civil rights through the courts and legislature, and in communities. The ACLU continues to support sanctuary jurisdictions and policies across the United States, and actively opposes laws that would restrict the continued existence of sanctuary jurisdictions (ACLU Response to "Sanctuary City" Legislation, n.d.).

\section{Challenges to Oregon's Sanctuary Policy}

Movements to Repeal Oregon Sanctuary Law

The original Oregon sanctuary law was passed in 1987 with 54 "yes" votes, 3 "no" votes, and 3 abstentions (Sanctuary Policies, 2019). This law matured significantly from some of the 
original policies of Oregon, including the Black Exclusion Act and other legal actions taken to promote white supremacy and manifest destiny ideals (Nokes, 2020). Oregon has a long history of racism and exclusion towards people of color, starting with the indigenous groups who originally lived on the lands settlers took over. By the 1970s, racial profiling and discrimination towards immigrants and other people of color was especially bad, and attorney Rocky Barilla began working toward changing how local law enforcement could interact with federal immigration policies. The catalyst was a man named Delmiro Trevino, an American citizen of Mexican descent who had been publicly harassed by three Polk County sheriffs. Trevino then went to Barilla, who discovered that the Polk County officers were acting at the behest of the Immigration and Naturalization Service (INS), detaining people of color until the INS could deport them. Barilla filed a lawsuit and "managed to broker a deal with the U.S. Attorney's Office saying INS would no longer encourage local law enforcement over the phone to enforce federal immigration law in Oregon," a fight Barilla then continued after being elected to the Oregon legislature (1987 Sanctuary Law Passed With Bipartisan Support, 2018). The ACLU of Oregon at the time was sponsoring a project called the Willamette Valley Immigration Project (WVIP), led by Larry Kleinman, who was also one of the founders of Oregon's largest farmworker union, Pineros y Campesinos Unidos del Noroeste (PCUN). These were the two main groups asking Barilla to sponsor the sanctuary law in the years after Trevino's lawsuit, eventually culminating in the passage of Oregon's sanctuary law, ORS 181.850 (now 181A.820), the Oregon Enforcement of Federal Immigration Laws Policy (1987 Sanctuary Law Passed With Bipartisan Support, 2018).

Multiple attempts have been made to repeal this law since 2003, shortly after the creation of the group Oregonians for Immigration Reform (OFIR). Members of Oregon's House and 
Senate began to introduce bills relating to "criminal aliens," enforcing federal immigration laws, and other bills that would nullify the sanctuary law (Oregon's History as a Sanctuary State, 2018). All of these bills died in discussion, and it was not until 2018, with Oregon Measure 105, that repeal was put to a vote. A “yes" vote for Measure 105 would have repealed Oregon's sanctuary law, but the majority of voters $(66.46 \%)$ voted "no" in order to keep the law in place (Oregon Measure 105, Repeal Sanctuary State Law Initiative, 2018).

\section{Recent Tension Between Federal Immigration Policy and Enforcement}

Federal immigration law has changed in the last five years with the beginning of the Trump administration. Trump endorsed federal bills in favor of severely restricting immigrant access to the country (Nakamura, 2017), and tried to terminate important programs for migrants like the Deferred Action for Childhood Arrivals (DACA) program (Rampell, 2020). Federal agencies like Immigration and Customs Enforcement (ICE) have been tasked with rounding up undocumented immigrants to put them in detention centers since 2017 (Roth, 2017; Armus, 2019). ICE puts out a nonbinding request called a detainer that "a state or local law enforcement agency maintain custody of an individual for up to 48 hours beyond the time the individual otherwise would have been released" (Sanctuary Policies: An Overview, 2020). Local sanctuary declarations often refuse to comply with immigration detainers, and various courts have repeatedly upheld the voluntary nature of the detainer requests, siding with those who do not comply (Sanctuary Policies: An Overview, 2020). A. Naomi Paik also explains that "while local sanctuary declarations cannot prevent ICE from using its own staff and resources to execute its work, they do resolve to deny collaboration with ICE” (Paik, 2017). 
The presence of ICE in the Pacific Northwest, particularly in Portland, has been widely contested. Many people fear for their own safety and the safety of their friends and families. After the inauguration of Donald Trump in early 2017, there were many rumors of ICE raids in various Oregon cities and towns, and occasionally ICE would actually show up in unmarked cars and arrest people off of the street, like they did to Saul Loeza and others from the Woodburn area (Parks, 2017). Leading up to the summer of 2019, Trump spent several weeks exaggerating the scale of ICE raids that would happen across the US, which led to a movement of information being spread regarding how to stay safe if contacted by ICE and how to report interactions with ICE directly to the ACLU branches in Oregon and other affected areas (Oregon Immigration Resource Information is Power When it Comes to ICE in our Communities, 2019). Given the increased threats to undocumented migrants, it is even more essential to understand the benefits of sanctuary policy in local and state laws.

\section{The Benefits of Sanctuary City Policy}

Despite challenges to the policy, Oregon's sanctuary law continues to have clear positive impacts for both migrant groups and the broader Portland community. These impacts include laying the foundation for an increase in community safety and extending the reach of immigrant and refugee-focused organizations.

\section{Conditions for Community Safety}

One of the most important factors for community success, particularly in sanctuary communities and areas where many migrants live regardless of legal status in the country, is the level of comfort and sense of security those migrants are able to achieve with their surroundings. 
This security can come from many different areas of life, including sanctuary policies themselves and not needing to stay under the radar of local law enforcement to avoid deportation or imprisonment. Once that burden of fear is lifted, it becomes much easier for migrants to integrate themselves into society. As people become more comfortable with their neighborhoods and communities, they might be more likely to participate in community groups and activities, and create true homes for themselves in the United States (Parks, 2017).

Sanctuary politics are also a notable way to encourage interaction between migrants and other residents of the United States, whether they be citizens or within the various other categories of residents. Sanctuary policy allows undocumented residents to feel comfortable making connections with their neighbors to feel safe and supported where they have chosen to live. Then, as citizens and legal residents form a sense of community and friendship with their neighbors, they are more likely to feel protective of those people regardless of the neighbors' legal residential status.

Part of creating and maintaining a safe community comes from the amount of crime and the response to that crime by local police. Many of the conservative Republican government officials that are against the institution of sanctuary spaces in the United States claim that sanctuary cities cause crime rates to increase because of the number of unauthorized residents living there. Some people, such as the current governor of Texas Greg Abbott, believe sanctuary city policies enable criminals by physically "hiding" or "shielding" undocumented migrants from federal law that says they are not allowed to live there, essentially determining that the cities' and local law enforcement agencies are committing crimes as well (McGlinchy, 2017). A common reason some people believe sanctuary policy causes an increase in crime is that these stable communities could see an increase in reported crimes without an increase in the actual rate 
of crime because undocumented residents are less afraid to interact with local authorities, and therefore more likely to call the police if they witness something illegal (O'Brien et al., 2019). However, while it is important to recognize that these statistical increases in crime rate are not necessarily correlated with an increase in the actual rate of crime, the reduced threat of deportation upon arrest to residents of these cities and states could also lead to an increase in the overall crime rate. Because local authorities of most sanctuary cities are not required to keep lists of immigration status and do not share immigration status with federal enforcement agencies, people arrested for criminal offenses are less likely to face illegal immigration charges at the same time (Hausman, 2020).

There is substantial debate among journalists and scholars about whether sanctuary city policies actually increase or decrease crime rates. It is difficult to determine the real effect of those policies because of the wide variety of data available and the opinions that surround the topic as a whole. Often, political opinion and the way politicians use crime rate data influence how people form their own opinions of sanctuary policy, regardless of data from the other side. While it is difficult to determine a direct correlation between sanctuary policy and crime rates, there is evidence crime has dropped overall. 


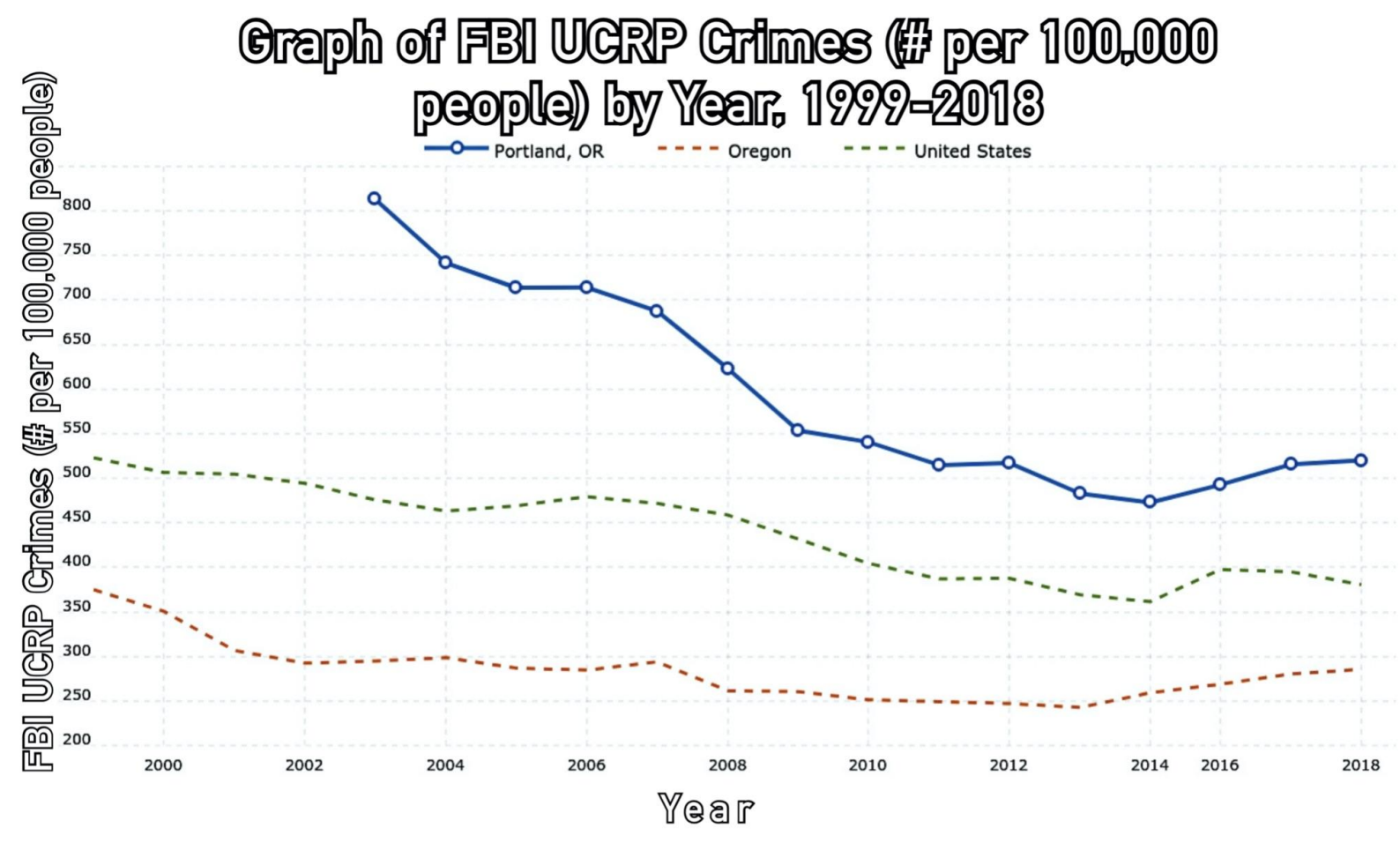

Figure 1. Graph of violent crime rates in Portland, OR since 1999. The horizontal axis is the year compared to the number of crimes per 100,000 people as tracked by the FBI UCRP on the vertical axis (Macrotrends, n.d.).

Since 1999, Portland has seen an overall decrease in the rate of the violent crimes tracked by the FBI's Uniform Crime Reporting Program, including robbery, aggravated assault, and murder/homicide (Macrotrends, n.d.). The United States as a whole has also seen a net decrease in violent crimes, and runs a similar path to the state of Oregon for offenses like property crime, burglary, and motor vehicle theft. While this decrease in crime cannot be attributed directly to sanctuary policy, it does coincide with the years of Oregon's sanctuary policy and its increasing migrant and undocumented resident population (Macrotrends, n.d.).

In addition to facilitating a decrease in crime, sanctuary policy encourages connections to community resources, specifically law enforcement. In 2017, David Rogers, the executive 
director of the ACLU of Oregon, talked to Street Roots about the fragile relationship between local police and undocumented residents due to the active ICE operations in the state, saying that "people will be less likely to engage law enforcement when there is a problem. There is a trust in our system that needs to be in place for a society to work and for everyone to be safe" (Green, 2017). Rogers was specifically talking about ICE's practice of profiling and arresting undocumented people in courthouses, and how that affects the willingness of those undocumented people to participate in the justice system, but his statement applies to all areas of life. When undocumented residents know they are protected by sanctuary policy, they are more likely to trust local authorities because they are able to better separate the fear of deportation from regular interactions with authorities, and can better utilize those law enforcement resources available. Confidence in the enforcement of sanctuary policy is a major factor in the establishment and continued success of sanctuary policies in other jurisdictions as well (Bojorquez, 2020).

Sanctuary policy might also make undocumented residents more willing to enroll their children in all sorts of state-level programs, including the Portland Police Bureau's recent youth violence prevention and community investment programs. Partially as a result of the 2020 Black Lives Matter movement, the Portland City Council voted to remove $\$ 15$ million from the Portland Police Bureau budget in June 2020 (Bernstein, 2020). A number of jobs were also terminated with this budget cut, so the city of Portland has been looking to invest more time and resources into programs like the Office of Youth Violence Prevention and the Community Peace Collaborative, which both work to intervene in and prevent gang violence in the city. Sanctuary policy can be effective in removing the fear undocumented residents have of participating in these beneficial programs. Efforts to make the city a safer place for everyone benefit resident 
migrants as well, for several reasons. Focusing on youth violence prevention is a way to help community members, regardless of legal residential status, start off on the right path, staying in school and learning about the opportunities that can come from continuing education and staying out of trouble. For adults, and especially migrant adults, the safety level of a neighborhood is often overlooked for the affordability of the neighborhood, but if neighborhoods are made progressively safer this becomes less of a burden on people with children. Children with less exposure to violence are less likely to fall into a pattern of violence themselves, thus creating more opportunities for them as they grow up.

\section{Expanding the Capacity of Immigrant and Refugee-Focused Organizations}

Nonprofit, migrant-focused community organizations like IRCO, Causa, the MPD, and the ACLU work very hard to establish migrants within society, and they are able to continuously provide for their communities because of the continued success of sanctuary policy in Oregon, for several reasons. Without the legal background of the state's sanctuary policy, these groups would be fighting for much more than the integration of undocumented migrants into American society. As an example of this, the ACLU websites for states that do not have any kind of sanctuary policies in place usually have a statement similar to: "The ACLU of Florida is dedicated to expanding and enforcing the civil liberties and civil rights of immigrants and to combating public and private discrimination against these groups" (Immigrants' Rights, 2018). This is a recognition that undocumented residents often are not granted access to the same civil rights and liberties that citizens and lawful residents have, regardless of their amount of time spent living in the United States and the roots laid down in the country. This is counterproductive to the integration of migrant communities into society through legislation, because when a 
legislative body has to work to grant migrants any protections under the law in the first place, efforts are being taken away from integration, and making the process unnecessarily long and complicated.

In Oregon, where state policy and the missions of smaller organizations align, legal organizations like the ACLU and MPD can step up and promote proactive state-level legislation. According to David Rogers, from his 2017 interview with Street Roots: "In Oregon, there are areas where we can actually advance civil rights and liberties and pass important reforms... There are opportunities to pass important tenant protections, advance housing stabilization, and push back on the criminalization of homelessness. We can advance smart justice and pass a landmark bill to address law enforcement profiling" (Green, 2017). It is most often the actions of these nonprofit organizations that trigger legislative action in the first place, because they are approachable bodies with influence in the realm of state law. There is always a need for new legislation, but the making of new laws has to stem from injustices experienced in daily life, which is how organizations like the ACLU of Oregon choose to be proactive in planning legislation to decrease the experiences of injustice before they become a bigger problem.

The nature of government is to leave gaps in policy implementation that can be filled in later, which makes the existence of various migrant-focused organizations like IRCO and Causa necessary because they can provide needed services outside of direct government influence, and in place of government-run institutions. It is especially important for groups not funded by the government to take on this responsibility because sanctuary is not a federally mandated law. This means that state governments with sanctuary policies do not receive money from the federal government specifically for sanctuary programs, leaving those states with little to no money to fund programs independently, and leaving nonprofit and privately operated organizations to find 
funding through private donors, grants, and elsewhere (Correal, 2020). While it can be a burden for organizations to find their own funding, the ambiguity regarding the policy's implementation allows organizations to have more flexibility with their programming. They can involve more community members in the process of obtaining funding, by branching out into service areas they might not have before and expanding their own operations to include as many social groups as possible.

\section{Conclusion}

Sanctuary policies are an active part of the continued integration of migrant groups into the United States because they continue to protect undocumented residents living in the country. These policies require a group of nonprofit organizations and law enforcement programs to provide key resources, particularly for undocumented migrants, but also for all noncitizen residents in a community. This thesis argues that the sanctuary policy in Oregon law positively impacts the lives of migrants to Portland by laying the foundation for an increase in community safety and by expanding the capacity of immigrant and refugee-focused institutions. Oregon's migrant communities include undocumented residents and residents with refugee status; in Oregon, these include large groups of undocumented migrants from South and Central America as well as refugee groups from Slavic countries. Migrant community groups benefit from positive interactions with law enforcement that stem from trusting that the sanctuary policy in place will protect their legal residency status, regardless of what that is. These migrant communities also benefit from the work of local nonprofit organizations like IRCO and the ACLU of Oregon, as well as other organizations that work towards the continued integration of migrants and migrant groups into society. These positive impacts reinforce the necessity of 
sanctuary policies, especially in comparison to the federal immigration policies of the Trump administration that sought to harm and displace migrants. As the lifespan and persistence of Oregon's sanctuary policy clearly shows, sanctuary policies are long-lasting and can provide needed protection for migrants even during federal administrations that are hostile to immigration.

I have outlined all the ways sanctuary policies are beneficial to societies, but moving forward there needs to be more effort to fund services that sanctuary policies enable, so that positive changes can continue to occur and the burden does not have to fall to a group of nonprofit organizations. While sanctuary policy allows these organizations to do really important and proactive legislative work, it is important to recognize that sanctuary policy alone is not enough because it does not provide the necessary funding to implement those positive changes. Providing funding for sanctuary policy will continue to aid with migrant integration into society, and will ensure that migrants have the same economic and social opportunities as citizens. 


\section{References}

ACLU Response to "Sanctuary City" Legislation. (n.d.). ACLU. Retrieved from https://www.aclu.org/aclu-response-sanctuary-city-legislation

Armus, T. (2019, February 8). Calling it 'the new normal,' feds arrest 200 undocumented immigrants in NC this week. The Charlotte Observer. Retrieved from https://www.charlotteobserver.com/news/politics-government/article225944480.html

Ayers, A. (2018, July 31). Immigrants and Public Benefits: What Must States and Localities Provide? Albany Law School: Government Law Center. Retrieved from https://www.albanylaw.edu/centers/government-law-center/Immigration/explainers/Pages /Immigrants-and-Public-Benefits-What-Must-States-and-Localities-Provide-.aspx\#_ednre f5

Bernstein, M. (2020, October 2). Portland on course to have most deadly spate of violence in at least six years. The Oregonian/Oregonian Live. Retrieved from https://www.oregonlive.com/crime/2020/10/portland-on-course-to-have-most-deadly-spat e-of-violence-in-at-least-six-years.html

Bojorquez, K. (2020, June 15). California's sanctuary law upheld by Supreme Court. Here's what it means. The Sacramento Bee. Retrieved from https://www.sacbee.com/news/politics-government/capitol-alert/article243546072.html

Causa. (2020, August 14). About Us. Retrieved from https://causaoregon.org/about-us/

Cohn, D., Passel, J. S., \& Bialik, K. (2019, November 27). Many immigrants with Temporary Protected Status face uncertain future in U.S. Retrieved from https://www.pewresearch.org/fact-tank/2019/11/27/immigrants-temporary-protected-statu s-in-us/ 
Colbern, A., Amoroso-Pohl, M., \& Gutierrez, C. (2019, June). Contextualizing Sanctuary Policy Development in the United States: Conceptual and Constitutional Underpinnings, 1979 to 2018. Fordham Urban Law Journal, 46(3), 489+. Retrieved from https://ink-gale-com.proxy.lib.pdx.edu/apps/doc/A592339978/AONE?u=s1185784\&sid= $\underline{\text { AONE\&xid }=08 \mathrm{c} 9873 \mathrm{a}}$

Correal, A. (2020, February 26). Trump Can Withhold Millions From ‘Sanctuary’ States, Court Rules. The New York Times. Retrieved from https://www.nytimes.com/2020/02/26/nyregion/sanctuary-cities-funding.html

Curry-Stevens, A. \& Coalition of Communities of Color (2014). The Slavic Community in Multnomah County: An Unsettling Profile. Portland, OR: Portland State University.

Green, E. (2017, February 2). David Rogers: ACLU of Oregon's role in the resistance. Street Roots. Retrieved from https://www.streetroots.org/news/2017/02/02/david-rogers-aclu-oregons-role-resistance

Hardwick, Susan W. (2006). "Nodal Heterolocalism and Transnationalism at the United States-Canadian Border.” Geographical Review, vol. 96, no. 2, Apr. 2006, pp. 212-228. ProQuest.

Hardwick, S. W., \& Meacham, J. E. (2005). Heterolocalism, Networks of Ethnicity, and Refugee Communities in the Pacific Northwest: The Portland Story. The Professional Geographer, 57(4), 539-557. doi:10.1111/j.1467-9272.2005.00498.x

Hausman, D. K. (2020). Sanctuary policies reduce deportations without increasing crime. Proceedings of the National Academy of Sciences, 117(44), 27262-27267. doi:10.1073/pnas.2014673117 
Houston, S. (2019). Conceptualizing Sanctuary as a Process in the United States. Geographical Review, 109(4), 562-579. https://doi.org/10.1111/gere.12338

Hume, S. E., \& Hardwick, S. W. (2005). African, Russian, and Ukrainian Refugee Resettlement in Portland, Oregon. Geographical Review, 95(2), 189-209. doi:10.1111/j.1931-0846.2005.tb00362.x

Immigrants' Rights. (2018, October 23). ACLU of Florida. Retrieved from https://www.aclufl.org/en/issues/immigrants-rights

Immigrants' Rights. (2019, February 17). ACLU of Oregon. Retrieved from https://www.aclu-or.org/en/issues/immigrants-rights

IRCO 2019 Impact Report (Rep.). (2019). Portland, OR: IRCO. Retrieved from https://irco.org/assets/files/financials/IRCOimpactreport2019 web.pdf.

Lotspeich, K., Fix, M., Perez-Lopez, D., \& Ost, J. (2003). A Profile of the Foreign-Born in the Portland, Oregon Tri-County Area (Rep.). Retrieved from https:/www.urban.org/sites/default/files/publication/59521/410917-A-Profile-of-the-Fore ign-Born-in-the-Portland-Oregon-Tri-County-Area.PDF.

McGlinchy, A. (2017, May 8). Texas Gov. Greg Abbott Signs Controversial 'Sanctuary Cities' Law. NPR. Retrieved from https://www.npr.org/2017/05/08/527452803/texas-gov-greg-abbott-signs-controversial-sa nctuary-cities-law

Metropolitan Public Defender. (2021). About Us. Retrieved from https://www.mpdlaw.com/about-us-2/

Morrison, P. A., \& Swanson, D. A. (2019, Jul 16). Sanctuary cities get a census bonus; localities where migrants live — or are detained — will get a decade long windfall of federal dollars. 
Wall Street Journal (Online) Retrieved from

http://stats.lib.pdx.edu/proxy.php?url=http://search.proquest.com/docview/2258385311?a $\underline{\text { ccountid }=13265}$

Nakamura, D. (2017, August 3). Trump, GOP senators introduce bill to slash legal immigration levels. Washington Post. Retrieved from https://www.washingtonpost.com/news/post-politics/wp/2017/08/02/trump-gop-senators-t o-introduce-bill-to-slash-legal-immigration-levels/?hpid=hp_hp-top-table-main_pp-immi gration-940am:homepage/story

New American Economy. (2020). New Americans in Portland, OR: A Snapshot of Demographic and Economic Characteristics of Immigrants in the City (Rep.). Portland, OR: The City of Portland.

Nokes, G. (2020, July 6). Black Exclusion Laws in Oregon. In Oregon Encyclopedia. Retrieved from https://www.oregonencyclopedia.org/articles/exclusion_laws/\#.YGqA_tzYrrc

O’Brien, B. G., Collingwood, L., \& El-Khatib, S. O. (2019). The Politics of Refuge: Sanctuary Cities, Crime, and Undocumented Immigration. Urban Affairs Review, 55(1), 3-40. https://doi.org/10.1177/1078087417704974

Oregon Measure 105, Repeal Sanctuary State Law Initiative (2018). (n.d.). Retrieved October 29, 2020, from https://ballotpedia.org/Oregon Measure 105, Repeal Sanctuary State Law Initiative ( $\underline{2018)}$

Oregon's History as a Sanctuary State. (2018, March 27). Stop Oregon Sanctuaries. Retrieved from https://www.stoporegonsanctuaries.org/info/oregon-history-sanctuary-state 
Paik, A. N. (2017). Abolitionist futures and the US sanctuary movement. Race \& Class, 59(2), 3-25. https://doi.org/10.1177/0306396817717858

Parks, C. (2017, April 7). 'Everyone is affected.' Immigration raids turn Oregon city into ghost town. The Oregonian/Oregonian Live. Retrieved from https://www.oregonlive.com/pacific-northwest-news/2017/04/woodburn_taught_latinos_t o_dre.html

Point: Sanctuary Cities Protect Local Economies and Communities. (2019). Points of View: Sanctuary Cities, 1.

Portland OR Crime Rate 1999-2018. (n.d.) Macrotrends. Retrieved February 7, 2021, from https://www.macrotrends.net/cities/us/or/portland/crime-rate-statistics

Rampell, C. (2020, October 29). Trump didn't build his border wall with steel. He built it out of paper. The Washington Post. Retrieved from https://www.washingtonpost.com/opinions/2020/10/29/trump-immigration-daca-family-s eparation/?arc404=true

Roth, S. (2017, March). ICE arrests 84 people during 3-day sweep of Pacific Northwest. KGW8 News. Retrieved from https://www.kgw.com/article/news/local/ice-arrests-84-people-during-3-day-sweep-of-pa cific-northwest/283-426890395

Sanctuary Policies. (2019). Oregonians for Immigration Reform. Retrieved November 4, 2020, from http://www.oregonir.org/book/export/html/2414

Sanctuary Policies: An Overview. (2020, October 21). American Immigration Council. Retrieved from https://www.americanimmigrationcouncil.org/research/sanctuary-policies-overview 
Tebben, C. (2017). IRCO Community Needs Assessment: 2017 Report (Rep.). Portland, OR: IRCO. Retrieved from https://irco.org/assets/files/financials/IRCO\%202017\%20CNA\%20Report.pdf

The Refugee Act. (2012, August 29). Office of Refugee Resettlement. Retrieved from https://www.acf.hhs.gov/orr/policy-guidance/refugee-act

United States Census Bureau. (2019). Place of Birth by Nativity and Citizenship Status (2019: ACS 1-Year Estimates Detailed Tables). [Data File]. Retrieved from https://data.census.gov/cedsci/table?g=1600000US4159000\&tid=ACSDT1Y2019.B0500 2

U.S. Annual Refugee Resettlement Ceilings and Number of Refugees Admitted, 1980-Present. (2020, November 15). Migration Policy Institute. Retrieved from https://www.migrationpolicy.org/programs/data-hub/charts/us-annual-refugee-resettlemen t-ceilings-and-number-refugees-admitted-united

Valderrama, A. (2017). 37277 Declare the City of Portland a Welcoming City, Sanctuary City, and an Inclusive City for all resolution (United States, The City of Portland Oregon, Auditor's Office). Portland, OR: Auditor's Office.

Villazor, R. C., \& Gulasekaram, P. (2019). Sanctuary Networks. Minnesota Law Review, 103(3), $1209-1283$

1987 Sanctuary Law Passed With Bipartisan Support. (2018, March 14). OneOregon. Retrieved from http://www.oneoregon.org/stories/barilla-1987-sanctuary-law-passed-broad-bipartisan-su pport/ 